\title{
KAJIAN INDEKS GLIKEMIK BERAS ANALOG BERBASIS TEPUNG MOKAF, TEPUNG GARUT DAN TEPUNG KACANG MERAH
}

\author{
(Study of Glicemic Index of Analog Rice Made of Mocaf Flour, Arrowroot \\ Flour and Red Bean Flour)
}

\author{
Sri Budi Wahjuningsih ${ }^{1}$ \\ 'Jurusan Teknologi Hasil Pertanian, Fakultas Teknologi Pertanian, \\ Universitas Semarang, Jl. Soekarno Hatta Semarang \\ (sribudiwahjuningsih@yahoo.com)
}

\begin{abstract}
ABSTRAK
Tepung mokaf dan tepung garut dapat dikembangkan sebagai sumber karbohidrat non beras pada pembuatan beras analog.Tepung kacang merah digunakan sebagai sumber protein dan kandungan amilosanya yang tinggi dapat membantu membentuk butiran beras analog..Pembuatan beras analog menggunakan teknologi ekstrusi sehingga menghasilkan karakteristik produk seperti beras. Tujuan penelitian ini adalah untuk menentukan indeks glikemik beras analog berbasis tepung mokaf, tepung garut dan tepung kacang merah sebagai pangan alternative bagi penderita diabetes. Penelitian ini menggunakan Rancangan Acak Lengkap, satu faktor yaitu perbandingan tepung mokaf, tepung garut dan tepung kacang merah dengan 5 taraf perlakuan, yaitu B1: 90\%: o\% : 10\%; B2 80\%:10\%: 10\%; B3 70\%: 20\% : 10\%; B4 60\%: 30\%; 10\%; dan B5 50\%: 40\%: 10\%.Penelitian ini terdiri dari tahapan: persiapan bahan, formulasi tepung komposit sesuai perbandingan untuk pembuatan beras analog dan pengujian indeks glikemiknya. Formula terbaik beras analog dengan indeks glikemik 74 diperoleh dari perlakuan $B_{5}$ yaitu perbandingan tepung mokaf, tepung garut dan tepung kacang merah 50\%:40\%:10\%.
\end{abstract}

\begin{abstract}
Mocaf flour and arrowroot flour can be exploited as a source of non rice carbohydrate in analog rice. Red bean flour was used for protein source and the high content of amylose could help to shape the analog rice as natural. The use of extrusion technology can be used to produce analog rice which has similar characteristics with rice. The purpose of this study was to determine the glycemic index of the analog rice based mocafflour, arrowroot and red bean flour as an alternative food for people with diabetes mellitus. This research uses a Completely Randomized Design, one factor is the ratio of mocaf flour, arrowroot flour and read bean flour with 5 levels of treatment namely B1: $90 \%$ : o\% : 10\%; B2 80\%:10\%: $10 \%$; B3 70\%: $20 \%: 10 \%$; B4 60\%: 30\%; $10 \%$; dan B5 50\%: 40\%: $10 \%$. The study was conducted in several phases: preparation, formulation phase of flour composite to make analog rice, and testing phase of chemical properties and testing for the glycemic index of the analog rice. The best formula of analog rice based on the glycemic index was treated $B_{5}$ (50\%: 40\%: 10\%). Compositions of The formula contain glycemic index 74 .
\end{abstract}

Keywords: Analog rice, mokafflour, arrowroot flour, red bean flour and the glycemic index 


\section{PENDAHULUAN}

Diabetes mellitus adalah gangguan metabolisme karbohidrat yang ditandai dengan meningkatnya kadar gula dalam darah (hyperglycemia) karena kurang maksimalnya pemanfaatan gula oleh tubuh sebagai sumber energi akibat berkurangnya hormon insulin yang diproduksi oleh pankreas atau tidak berfungsinya hormon insulin dalam menyerap gula secara maksimal (ADA, 2004). Prevalensinya meningkat sebagai akibat dari peningkatan kemakmuran (Pusat Diabetes dan Lipid RSCM, 2002). Beberapa penelitian epidemiologi menunjukkan adanya kecenderungan peningkatan angka insiden dan prevalensi diabetes mellitus tipe 2 di berbagai penjuru dunia. Sedangkan di Indonesia, WHO memprediksi kenaikan jumlah pasien menjadi sekitar 21,3 juta pada tahun 2030 (Soegondo et al, 2006).

Diabetes mellitus merupakan penyakit kronik yang tidak dapat disembuhkan tetapi sangat potensial untuk dicegah dan dikendalikan melalui pengelolaan DM, salah satunya adalah pengaturan diet di samping mengkonsumsi pula obat berkhasiat hipoglikemik. Pilihan akan jenis bahan makanan dengan kandungan zat gizi tertentu merupakan upaya pengendalian yang diberikan secara seimbang sehingga tidak menimbulkan puncak (peak) glukosa darah yang tinggi setelah makan (Pusat Diabetes dan Lipid RSCM, 2002). Salah satu pendekatan yang dilakukan adalah melalui Indeks Glikemik.

Konsep IG menekankan pentingnya mengenal bahan pangan, khususnya karbohidrat berdasarkan respon glukosanya (Siagian, 2004). Dengan mengetahui IG pangan, penderita DM secara mandiri akan dengan mudah dapat memilih pangan yang dapat mengenyangkan tetapi tidak cepat menaikkan kadar glukosa darah. Memilih makanan dengan IG rendah secara tidak langsung berarti mengkonsumsi makanan yang beraneka ragam. Oleh karena itu, diet dan pemilihan makanan dengan konsep IG mendukung pula upaya penganekaragaman pangan (Siagian, 2004).

Saat ini sudah banyak berkembang sumber karbohidrat yang memiliki bentuk dan gizi yang mirip dengan beras, yaitu beras analog (artificial rice). Beras analog adalah beras yang dibuat dari bahan non padi dengan kandungan karbohidrat mendekati atau melebihi beras yang terbuat dari tepung lokal atau tepung beras (Samad, 2003). Pengembangan beras analog juga merupakan salah satu bentuk usaha untuk mempercepat program diversifikasi pangan, terutama makanan pokok sebagai alternatif pengganti beras. Penelitian terkait dengan beras analog sudah banyak dilakukan, sebagian besar hanya terfokus pada kandungan fisik, kimia dan organoleptik tetapi belum banyak yang meninjau sampai nilai indeks glikemiknya. Tepung mokaf, tepung garut dan tepung kacang merah berpotensi menjadi salah satu bahan baku pembuatan beras analog karena potensinya ada, proses pembuatannya mudah, harga relatif terjangkau dan memiliki karakteristik yang mudah dibentuk. Penelitian beras analog dari tepung mokaf dengan tepung kacang-kacangan sebagai sumber protein, salah satunya adalah tepung kacang merah untuk melihat karakteristik sifat fisik, kimia dan organoleptik (Wahjuningsih dan Susanti, 2017).

Tepung mokaf adalah tepung ubi kayu yang diproses dengan cara fermentasi dengan menggunakan biang (Wahjuningsih, 2012). Sebagai makanan sumber protein, kacang merah (Vigna angularis) merupakan bahan makanan dengan kandungan serat yang tinggi dan berindeks glisemik rendah yaitu 26 (Marsono, 2002), sehingga memiliki sifat viskositas yang besar dan absorbsi yang rendah. Setiap 100 g tepung kacang merah menyediakan serat sekitar 10 g yang terdiri dari serat larut dan serat tidak larut (Wahjuningsih dan Kunarto, 2013). Serat larut yang tersedia secara signifikan menurunkan gula darah, karena serat larut dapat menurunkan respon glikemik pangan (Nurfi, 2009). Namun penelitian yang dilakukan belum tertuju pada konsep IG untuk penyakit diabetes mellitus. Tepung garut ditambahkan dalam formulasi beras analog karena di antara beberapa jenis umbi-umbian ternyata garut mempunyai nilai IG yang paling rendah (14) (Marsono, 2002), sehingga penambahan tepung garut pada pembuatan beras analog berbasis tepung mokaf dan kacang merah diharapkan dapat menurunkan nilai indeks glikemiknya. 
Tujuan penelitian ini adalah menentukan indeks glikemik beras analog berbasis tepung mokaf, garut dan kacang merah sebagai pangan alternatif bagi penderita diabetes mellitus.

\section{BAHAN DAN METODE}

Jenis Penelitian yang digunakan adalah penelitian eksperimental. Penelitian ini dilaksanakan di Laboratorium Gizi Fakultas Teknologi Pertanian Universitas Gadjah Mada, Yogyakarta. Sampel penelitian ini adalah ubi kayu, umbi garut dan kacang merah, kemudian dilakukan formulasi untuk pembuatan beras analog.

Prosedur penelitian dimulai dari pembuatan Beras Analog dengan membuat tepung mokaf, tepung garut dan tepung kacang merah. Tepung mokaf dan tepung kacang merah dibuat dengan metoda yang sudah dilakukan oleh peneliti sebelumnya (Wahjuningsih, 2012; Wahjuningsih dan Kunarto, 2013). Tepung garut dibuat dengan cara mengupas umbi garut, kemudian dilakukan pencucian dan pengirisan. Selanjutnya dilakukan blansing selama 5 menit pada suhu $80^{\circ} \mathrm{C}$, kemudian ditiriskan dan dijemur pada suhu $50^{\circ} \mathrm{C}$ selama 12 jam. Chip yang dihasilkan kemudian digiling dan diayak dengan ukuran 8o mesh. Ketiga bahan tersebut dibuat formula sebagai tepung komposit untuk beras analog. Tepung komposit dibuat sesuai dengan perlakuan. Sebelumnya dilakukan pembuatan emulsi yang terdiri dari GMS, garam, aquades, minyak kelapa, dan karagenan, kemudian dicampur dengan tepung komposit dan dilakukan homogenisasi selama 5 menit, setelah itu dilakukan pengukusan selama 15 menit. Bahan yang sudah dikukus langsung dimasukkan ke dalam ekstruder untuk dicetak menjadi beras analog. Setelah terbentuk butiran selanjutnya dikeringkan dalam pengering kabinet selama 6 jam pada suhu $50^{\circ} \mathrm{C}$. Setelah itu dilakukan pengujian indeks glisemik terhadap beras analog yang dibuat. Berdasarkan data kandungan karbohidrat dan serat pangan pada penelitian sebelumnya (Wahjuningsih dan Susanti, 2017) dapat dilakukan perhitungan jumlah sampel yang harus dimakan oleh relawan dalam penentuan indeks glisemik, yaitu mengandung 50 g setara glukosa.
Pelaksanaan penentuan indeks glikemik dilakukan sebagai berikut: relawan yang sudah terpilih harus berpuasa selama 10 jam mulai malam hari, kemudian pada pagi harinya darah diambil dan dianalisis kadar gulanya (gula puasa). Kemudian kepada para relawan diberikan makanan standar yaitu 50 g glukosa. Pengambilan darah dan analisis gula darah diulangi lagi dengan interval 30 menit setelah makan, sebanyak 4 kali (30, 60, 90 dan 120 menit). Pada hari berikutnya dilakukan hal yang sama terhadap sampel beras analog, pada relawan yang sama. Dari kadar gula darah puasa dan setelah makan dapat dibuat grafik respon glukosanya dan dapat ditentukan indeks glisemiknya. Indeks glisemik merupakan ratio luas kurva respon glukosa makanan yang diuji dengan kurva respon glukosa makanan standar (glukosa). Kadar glukosa darah ditentukan dengan ACCU-CHECK glucometer-Roche Diagnostics GmbH, Germany seperti yang digunakan oleh peneliti terdahulu (Ihediohanma et al, 2012, Wahjuningsih et al., 2016). Penelitian ini telah mendapat ethical clearance dari Komisi Etik Penelitian Kesehatan Fakultas Kedokteran Universitas Gadjah Mada No.KF/FK/48o/EC, Tahun 2015.

Analisis data yang dilakukan adalah Rancangan Acak Lengkap, satu faktor yaitu perbandingan tepung mokaf, tepung garut dan kacang merah dengan 5 taraf perlakuan, yaitu B1: 90\%: o\% : 10\%; B2 80\%:10\%: 10\%; B3 70\% : 20\% : 10\%; B4 60\%: 30\%; 10\%; dan $\mathrm{B}_{5}$ 50\%: 40\%: 10\%. Penelitian diulang sebanyak 4 kali, selanjutnya data yang diperoleh dianalisis varian dan apabila ada perbedaan perlakuan dilanjutkan dengan Uji Duncan Multiple Range Test (DMRT) pada taraf 5\%.

\section{HASIL}

Karakteristik kimia beras analog yang sudah diteliti sebelumnya di antaranya adalah kadar amilosa dan serat pangan (Wahjuningsih dan Susanti, 2017). Serat pangan total merupakan hasil penjumlahan dari kandungan serat tak larut dan serat larut. Kandungan serat tak larut beras analog tepung mokaf, tepung garut dan tepung kacang merah berkisar antara 3.69\% sampai dengan $5.42 \%$ dan kadar serat larutnya 
berkisar antara $2.74 \%$ sampai dengan 3.73\%, sedangkan kadar amilosa beras analog mokaf berkisar antara $24.61 \%$ sampai dengan $26.40 \%$ (Wahjuningsih dan Susanti, 2017).

Kadar gula darah puasa dan posprandial (setelah mengkonsumsi beras analog) relawan dapat dilihat pada Tabel 1. Perubahan kadar gula darah sejak puasa sampai dengan dua jam setelah makan/ mengkonsumsi bahan uji dapat dilihat pada Gambar 1.

Pengujian kadar gula darah dilakukan setelah para relawan melakukan puasa selama 10 jam. Kemudian para relawan diberikan makanan yang akan diuji indeks glisemiknya dengan berat yang telah ditentukan (mengandung $50 \mathrm{~g}$ setara glukosa). Pengambilan darah dan analisis gula darah diulangi lagi dengan interval 30 menit setelah makan, sebanyak 4 kali (30, 6o, 90 dan 120 menit).

Hasil pengujian indeks glikemik beras analog pada Tabel 2 beras analog tepung mokaf, tepung garut dan tepung kacang merah mengalami penurunan berkisar antara $87(\mathrm{~B} 1)$ sampai dengan 74 (B5).

\section{PEMBAHASAN}

Hasil penelitian sebelumnya menunjukkan bahwa perbedaan komposisi tepung komposit berpengaruh sangat nyata terhadap kandungan serat tak larut dan serat larut pada beras analog tepung mokaf, tepung garut dan tepung kacang merah (Wahjuningsih dan Susanti, 2017). Beras analog dengan proporsi tepung garut lebih besar memiliki kandungan serat tak larut dan serat larut semakin meningkat, hal tersebut menyebabkan total serat pangannya juga semakin meningkat. Kandungan serat pangan total beras analog tepung mokaf, tepung garut dan tepung kacang merah lebih tinggi dibandingkan dengan kandungan serat pangan pada beras analog jagung putih yaitu $5,75 \%$ dan beras sosoh yaitu o,6\% (Ohtsubo et al, 2005). Makanan dikatakan sebagai sumber serat jika mengandung serat pangan minimal 3\%, sedangkan makanan tinggi serat jika mengandung serat pangan minimal $6 \%$. Sejalan dengan pernyataan tersebut maka beras analog yang dihasilkan dapat dikatakan sebagai makanan sumber serat pangan (Foschia et al, 2013).
Serat pangan adalah seluruh komponen polisakarida yang tidak dapat dihidrolisis oleh kerja usus manusia (Kusharto, 2006). Serat juga sering disebut sebagai unavailable carbohydrate, yaitu bagian dari dinding sel tanaman yang tidak dapat diserap oleh tubuh. Serat pangan memiliki karakteristik yang dibutuhkan dan dianggap penting dalam formulasi makanan fungsional (Cuenca et al, 2008). Serat pangan dalam bahan pangan akan mempengaruhi sifat bahan pangan tersebut. Semakin tinggi kadar serat, maka daya serap air juga akan semakin tinggi. Semakin tinggi kadar serat dalam bahan pangan, maka indeks glikemik bahan pangan tersebut akan cenderung semakin rendah (Siagian, 2004).

Serat pangan dalam tubuh manusia akan dicerna menjadi komponen undigestable dan komponen asam lemak rantai pendek, air, $\mathrm{CO}_{2}$ dan metana (Kusharto, 2006). Metabolisme serat berkaitan dengan kinerja dari bakteri yang ada di dalam usus besar. Pengaruh serat yang nyata terhadap metabolisme adalah peningkatan volume feses, memperpendek transit time di usus, melunakkan konsistensi feses dan dapat menghasilkan komponen asam lemak rantai pendek yang bermanfaat terhadap kesehatan. Mekanisme serat pada metabolisme gula darah berkaitan dengan fungsi dan karakteristik serat. Efek fisologis dan metabolik tergantung dari jenis serat yang dikonsumsi oleh pasien DM tipe 2. Serat larut air dapat menyerap cairan dan membentuk gel di dalam lambung. Gel memperlambat proses pengosongan lambung dan penyerapan zat gizi. Gel dapat memperlambat gerakan peristaltik zat gizi (glukosa darah) dari dinding usus halus menuju daerah penyerapan sehingga terjadi penurunan kadar glukosa darah (Gropper et al, 2005).

Semakin tinggi proporsi tepung garut dalam tepung komposit, maka kandungan amilosa dalam beras analog mokaf juga akan semakin tinggi (Wahjuningsih dan Susanti, 2017). Tepung garut dan tepung kacang merah memiliki kandungan amilosa yang tinggi, sehingga produk beras analog yang dihasilkan juga memiliki kandungan amilosa yang relatif tinggi, yaitu lebih dari $20 \%$.

Amilosa adalah polimer yang tersusun 
hampir seluruhnya dari D-Glukopiranosa dengan ikatan $\alpha[1-4]$ (Bemiller, 2007). Amilosa berpengaruh terhadap tekstur beras. Kadar amilosa dapat digunakan untuk memprediksi kekerasan gel pasta tepung yang terbuat dari beras. Beras dengan kandungan amilosa tinggi memberikan efek IG rendah daripada beras dengan kandungan amilosa yang rendah (Frei et al., 2003).

Indeks glikemik dihitung berdasarkan perbandingan antara luas kurva kenaikan glukosa darah setelah mengkonsumsi pangan yang diuji dengan kenaikan glukosa darah setelah mengkonsumsi makanan standar, yaitu glukosa (Marsono, 2002) atau roti tawar (Brouns et al, 2005). Respon glikemik ditunjukan oleh kurva fluktuasi dari penyerapan glukosa dalam darah.

Pangan ber-IG rendah dan tinggi dapat dibedakan berdasarkan kecepatan pencernaan dan penyerapan glukosa serta fluktuasi kadarnya dalam darah (Hoerudin, 2012). Pada Gambar 1 dapat dilihat bahwa respon glukosa darah B1 pada $\mathrm{P}_{30}$ lebih cepat jika dibandingkan dengan P6o, P9o, dan P120. Namun pada Gambar 2 dapat dilihat bahwa $\mathrm{B}_{5}$ mempunyai respon glukosa darah yang paling lambat. Hal ini disebabkan karena B1 mempunyai indeks glikemik yang lebih tinggi jika dibandingkan dengan $\mathrm{B}_{2}, \mathrm{~B}_{3}, \mathrm{~B}_{4}$, dan $\mathrm{B}_{5}$. Ini dapat terjadi karena pangan yang mempunyai indeks glikemik lebih rendah mengalami proses pencernaan lebih lambat, sehingga laju pengosongan perut pun berlangsung lambat. Hal ini menyebabkan suspensi pangan (crime) lebih lambat mencapai usus halus, sehingga penyerapan glukosa pada usus halus menjadi lambat (Arif et al, 2013).

Pada Tabel 2 dapat dilihat bahwa B1 mempunyai nilai indeks Glikemik 87 lebih tinggi dari B2 yang mempunyai indeks glikemik 84. Hal ini disebabkan karena B1 mempunyai komposisi tepung mokaf yang paling banyak yaitu 90\%. Hal ini dapat terjadi karena tepung mokaf dibuat dengan cara fermentasi sehingga komponen selulosa sudah terdegradasi menjadi komponen yang lebih sederhana selama proses fermentasi berlangsung. Hal tersebut menyebabkan beras analog dari tepung mokaf lebih mudah dicerna di dalam tubuh. Pangan yang mudah dicerna dan diserap menaikan kadar glukosa darah dengan cepat. Peningkatan kadar glukosa darah yang cepat ini memaksa pankreas untuk mengsekresikan insulin lebih banyak, oleh karena itu, kadar glukosa darah yang tinggi juga meningkatkan respon insulin (Siagian, 2004).

Perbedaan hasil penentuan indeks glikemik bahan pangan yang sama biasa terjadi (Hasan et al, 2011). Tidak ada nilai indeks glikemik yang pasti untuk sebuah bahan pangan. Pangan dengan jenis yang sama pun dapat memiliki Indeks Glikemik yang berbeda bila dimasak dan diolah dengan cara yang berbeda. Pengolahan dapat merubah struktur dan komposisi zat gizi penyusun pangan (Foster-Powel et al, 2002). Dari Tabel 2 dapat dilihat bahwa $\mathrm{B}_{5}$ mempunyai indeks glikemik 74 lebih rendah jika dibandingkan dengan $\mathrm{B}_{4}$ dan $\mathrm{B}_{3}$ yang mempunyai indeks glikemik 79 dan 8o. Hal ini disebabkan karena $\mathrm{B}_{5}$ mempunyai komposisi tepung mokaf paling sedikit jika dibandingkan dengan $\mathrm{B}_{3}$ dan $\mathrm{B}_{4}$. Perlakuan $\mathrm{B}_{5}$ mempunyai komposisi tepung mokaf paling sedikit, dan tepung garut paling banyak. Garut diketahui sebagai salah satu jenis umbi-umbian yang nilai indeks glikemiknya paling rendah yaitu 14 (Marsono, 2002), sehingga beras analog dengan tambahan tepung garut lebih banyak mempunyai nilai indeks glikemik yang lebih rendah. Selain itu garut juga mempunyai kadar serat pangan lebih tinggi 6.76\% dibandingkan dengan tepung mokaf $3.78 \%$. Serat pangan adalah dinding sel tanaman yang tidak tercerna di dalam usus halus tetapi terfermentasi di dalam usus besar menghasilkan asam lemak rantai pendek, sehingga konsumsi serat pangan dapat menunda kenaikan kadar glukosa darah. Keberadaan serat pangan dapat memengaruhi kadar glukosa darah (Fernandes et al, 2005). Secara umum, kandungan serat pangan yang tinggi berkontribusi pada nilai IG yang rendah (Trinidad et al, 2010). Dalam bentuk utuh, serat dapat bertindak sebagai penghambat fisik pada pencernaan. Serat dapat memperlambat laju makanan pada saluran pencernaan dan menghambat aktivitas enzim sehingga proses pencernaan khususnya pati menjadi lambat dan respons glukosa darah pun akan lebih 
rendah. Dengan demikian IG-nya cenderung lebih rendah. Semakin rendahnya nilai indeks glikemik kemungkinan juga dapat dikaitkan dengan kandungan amilosa yang semakin tinggi. Amilosa merupakan bagian dari rantai lurus yang dapat memutar dan membentuk daerah sulur ganda. Rantai lurus amilosa yang membentuk sulur ganda kristal tersebut tahan terhadap amilase dan tidak akan mudah mengalami degradasi oleh enzim $\alpha$ - amylase sehingga akan menurunkan respon glukosa darah dalam saluran cerna (Chaplin, 2002).

Hasil penelitian ini menunjukkan bahwa semakin tinggi komposisi tepung mocaf pada beras analog maka indeks glikemiknya akan semakin tinggi pula, di sisi lain jika semakin tinggi komposisi tepung garut pada beras analog makan indeks glikemiknya akan semakin rendah pula, walaupun penambahan tepung garut sampai $40 \%$ belum mampu menurunkan nilai IG sampai level rendah. Faktor - faktor yang dapat mempengaruhi indeks glikemik pangan di antaranya adalah cara pengolahan (tingkat gelatinisasi pati dan ukuran partikel), perbandingan amilosa dan amilopektin, tingkat keasaman dan daya osmotik, kadar serat pangan, kadar lemak, kadar pati resisten dan protein, serta kadar anti gizi pangan (Siagian, 2004).

\section{KESIMPULAN}

Penggunaan tepung mokaf, tepung garut dan kacang merah dalam pembuatan beras analog dapat menghasilkan beras analog dengan formula terbaik berdasarkan uji kimia dan indeks glisemik adalah perlakuan $\mathrm{B}_{5}$ (50\%: 40\%: 10\%). Komposisi formula tersebut mengandung indeks glisemik 74. Pemberian tepung garut sampai 40\% belum mampu menurunkan IG sampai kriteria rendah (di bawah 55).

\section{UCAPAN TERIMA KASIH}

Penelitian ini dibiayai oleh Program Penelitian Hibah Bersaing, Direktorat Riset dan Pengabdian Masyarakat, Direktorat Jenderal Penguatan Riset dan Pengembangan, Kementerian Riset, Teknologi dan Pendidikan Tinggi.

\section{DAFTAR PUSTAKA}

American Diabetes Association, 2004. Dietary Carbohydrate (amount and type) in Prevention and Management of Diabetes. (Statement). Diabetes Care 27: 2266-74.

Arif, AB, Budiyanto A., dan Hoerudin, 2013. Nilai Indeks Glikemik Produk Pangan dan Faktor - Faktor yang Mempengaruhinya. Balai Besar Penelitian dan Pengembangan Pascapanen Pertanian. Bogor.

Bemiller, JN., 2007. Starches, Modified Food Starches, and Other Products from Starches. Carbohydrate Chemistry For Food Scientists. AACC.

Brouns, F., I. Bjorck, K.N. Franyn, A.L. Gibbs, V. Lang, G. Slama, and T.M.S. Wolever., 2005. Glycemic index methodology. Nutrition Research Reviews(18):145-171.

Chaplin, M. 2002. Starch. http://www.sbu.ac.uk. Cited at 26 September 2015.

Cuenca AR, Suarez MJV, Aparicio IM., 2008. Soybean Seeds and its by-product Okara as Sources of Dietary Fibre. Measurument by AOAC and Englyst methods. Journal of Food chemistry (8): 1099-1105.

Fernandes, G.A. Velangi, and T.M.S. Wolever., 2005. Glycemic Index of Potatoes Commonly Consumed in North America. Journal of the American Dietetic Association (105) : 557-562.

Foschia M, Peressini D, Sensidoni A, Brennan CS., 2013. The Effects of Dietary Fibre Addition on The Quality of Common Cereal Products. Journal of Cereal Science (58) : 216-227.

Foster-Powell KF, Holt SHA, Miller JCB., 2002. International table of glicemic index and glycemic load values. American Journal of Clinical Nutrition (76) : 50-56.

Frei, M., Siddhuraju P. And Becker, K., 2003. Studies on The in vitro Strach Digestibility and The Glycemic Index of Six Different Indigenous Rice Cultivars from The Phillipines. Food Chemistry (83) : 395-402.

Gropper SS, Smith JL, Groff JL., 2005. Advance nutrition and human metabolism. $4^{\text {th }} \mathrm{ed}$. 
Australia: Thomson Wadsworth. (72-83): 108-119.

Hasan, V., Astuti, S, dan Susilawati., 2011. Jurnal Teknologi industridan Hasil Pertanian (16).

Hoerudin., 2012. Indeks glikemik buah dan implikasinya dalam pengendalian kadar glukosa darah. Buletin Teknologi pascapanen pertanian. Hlm 80-98.

Ihediohanma NC, Onuegbu NC, PeterIkeckhukwu AI \& Ojimba NC., 2012. A comparative study and determination of glycemic indices of three yam cultivars (Dioscorea rotundata, Dioscorea alata and Dioscorea domentorum). Pakistan Journal of Nutrition. (11): 547-552.

Kusharto, CM., 2006. Serat Makanan dan Peranannya Bagi Kesehatan. Jurnal Gizi dan Pangan (1): 45-54.

Marsono Y., 2002. Penentuan Indeks Glikemik Umbi-Umbian. Jurnal Agritech 22 (1): 13-16.

Nurfi A., 2009. Kacang Merah Turunkan Kolesterol dan Gula Darah. Jakarta : Depkes RI.

Ohtsubo K, Suzuki K, Yasui Y, Kasumi T., 2005. Bio-functional components in the processed pre-germinated brown rice by a twin-screw extruder. Journal of Food Composition and Analysis (18):303-316.

Pusat Diabetes dan Lipid RSCM., 2002. Penatalaksanaan Diabetes Mellitus Terpadu. Cetakan kedua. Jakarta : Balai Penerbit FKUI.

Samad, M.Y., 2003. Pembuatan Beras Tiruan(Artificial Rice) dengan Bahan Baku Ubi kayu dan Sagu. Prosiding Seminar Teknologi untuk Negeri 2003. Vol II. 36- 40/ Humas-BPPT/ANY, BPPT. Jakarta.
Siagian, R. A., 2004. Indeks Glikemik Pangan "Cara Mudah Memilih Pangan yang Menyehatkan”. Jakarta: Penebar Swadaya.

Soegondo, S., Rudianto A., Manaf A., Subekti I., Pranoto A, Asran P. M., 20o6. Konsesus Pengelolaan dan Pencegahan Diabetes Mellitus Tipe 2. Jakarta : Pengurus Besar Perkumpulan Endokrinoogi Indonesia.

Trinidad, T.P., A.C. Mallillin, R.S. Sagum, and R.R. Encabo. 2010. Glycemic index of commonly consumed carbohydrate foods in the Philippines. Journal of Functional Foods (2) : 271-274.

Wahjuningsih SB., 2012. Kajian Pembuatan Tepung Mokal dengan Metode Biang dari Berbagai Varietas Ubi Kayu. Prosiding Seminar Nasional Fakultas Agroindustri: 137- 146, ISBN 978-602-18810-0-2.

Wahjuningsih SB dan Kunarto, B., 2013. Pembuatan tepung mokal dengan penambahan biang fermentasi alami untuk beras analog. Jurnal Litbang Provinsi Jawa Tengah. (11) : 221-230. Wahjuningsih, S.B., Y. Marsono, D. Praseptiangga and B. Haryanto, 2016. Resistant starch contents and glycaemic index of sago (Metroxylon spp.) starch and read bean (Phaseolus vulgaris) based analogue rice. Pakistan Journal of Nutrition 15 (7) : 667-672.

Wahjuningsih, S.B. dan Susanti S., 2017. Chemical, Physical and Sensory Charateristics of Analog Rice Developed from the Mocaf, Arrowroof, Red Bean Flour. International Symposium on Food and Agro-biodiversity (ISFA) 2017. 